\title{
Employability Skills Performance Score for Fresh Engineering Graduates in Malaysian Industry
}

\author{
Yuzainee Md Yusoff ${ }^{1}$, Mohd. Zaidi Omar ${ }^{2}$, Azami Zaharim², Azah Mohamed ${ }^{2} \&$ Norhamidi Muhamad $^{2}$ \\ ${ }^{1}$ College of Engineering, Universiti Tenaga Nasional, Selangor, Malaysia \\ ${ }^{2}$ Centre for Engineering Education Research, Faculty of Engineering and Built Environment, Universiti \\ Kebangsaan Malaysia, Selangor, Malaysia \\ Correspondence: Yuzainee Md Yusoff, College of Engineering, Universiti Tenaga Nasional, 43009 Kajang \\ Selangor, Malaysia. Tel: 60-3-8928-7243. E-mail: yuzainee@uniten.edu.my
}

Received: September 24, 2012 Accepted: November 7, $2012 \quad$ Online Published: November 30, 2012

doi:10.5539/ass.v8n16p140

URL: http://dx.doi.org/10.5539/ass.v8n16p140

\begin{abstract}
This paper presents a method to evaluate the performance score based on employability skills for new engineers using NSW - Normalised Skill Weight. NSW is calculated from data collected from 337 employers of engineering industries in Kelang Valley, Malaysia. A questionnaire constructed to collect employers' perspectives regarding the level of requirement for each employability skills based on their needs. Twelve types of businesses related to engineering field engaged in the survey. In an earlier publication, in EDUCON2011, the authors have presented the employability skills for an entry-level engineer as seen by Malaysian employers. The finding shows the rank of skills according to the level of requirement and there are weight differences among the skills required by the industries. The result of analysis offers a suggestion for employers and undergraduates to calculate employability skills score based on the Normalised Skill Weight performed by engineering graduates. Furthermore, employers, who need to evaluate the quality of engineering graduates during interviews, might find this approach as key performance score for the assessment process to select new engineers.
\end{abstract}

Keywords: employability skills, evaluation, score, engineering graduates, employers

\section{Introduction}

Today's industries demand every new employee to possess employability skills in order to succeed in a career. Leaders in government and industries have been called for new graduates to mastery the employability skills such as communication skills, teamwork, problem solving and decision making skills. They wanted the newly graduates be able to 'know-how' to deal with real-world problems. Consequently, higher education providers need to ensure that all graduates are qualified and competent in order to succeed in work and life in this new era of the global economy (Zaharim et al., 2010). Higher education providers, employers and government need to have a common understanding on set of skills should be performed by engineering graduates. As a result, several studies and projects had been conducted to determine the set of employability skills and presented a few numbers of frameworks related to employability skills (Zaharim et al., 2010; DEST., 2002; Zaharim et al., 2009). Zaharim et al. (2010) proposed a framework of engineering employability skills for Malaysian namely MEES, acronym of Malaysian Engineering Employability Skills. The framework comprises the technical and softskills that meet the accreditation's requirement and employers needs. However, standing in the way of integrating such skills is about measurement. Measuring a student's knowledge is discrete facts but measuring a student's skills and abilities to apply knowledge is ambiguous circumstances.

Therefore, this study focused on the development of a systematic and comprehensive performance measurement system for fresh engineering graduates in Malaysian industries using the balanced scorecard approach, where industries of Kelang Valley, Malaysia as a case. The objectives of this study are (1) to identify the preferred indicators to measure performance based on employers' perspectives; (2) to develop a valid and reliable performance measurement system using Normalized Skill Weight to measure fresh engineering graduates' performance with regard to technical skills and softskills that link to engineering fields.

This paper focuses only on the development of Performance Score, not how they are measured. It adopts the qualitative and quantitative approaches. A structured questionnaire has been designed for data collection that will 
establish numerical comparisons. The questionnaires are based on the qualitative findings and further study on the employers' perceptions.

\section{Literature Review}

Skill is an ability to perform a specific task (DEST, 2006), and employability is about having the capability to gain initial employment, maintain employment and obtain new employment if required (Hillage \& Pollard, 1998). Robinson defined the employability skills as the required skills to acquire, keep and doing well on a job (Robinson, 2000). Measuring the skills are difficult (Borghans et al., 2001), and various definitions and methods have been used to ease the problem. A report by Elena Silva, a Senior Policy Analyst, revealed that the skills "can be measured accurately and in a common and comparable way" (Borghans et al., 2001). Liz Reisner explained that there is a way to measure some of these skills (Borghans et al., 2001). Measurement is the process of quantification and action correlates with performance (Neely et al., 2002). Measures can be objective or subjective. Objective measures can be independently measured and verified. Subjective ones cannot (Simmons, 2000). Measurement is a necessary component of evaluation. It gives us data for determining the worth of the object being evaluated (Kaufman et al., 1997). Studies on employability skills differ with regards to direct or indirect measurement depends on occupational title, qualification and level of education, years of work experience and numbers of training (Ashton \& Green, 1998). Measuring the scores of the employability skills is subjective and depends on the perception of evaluators. The employability scores are determined by a combination of technical skills, soft skills, and personal knowledge of the individuals.

\section{Method}

The data used in this study is part of the data collected from engineering industries in the Kelang Valley, Malaysia, funded Universiti Kebangsaan Malaysia. This study uses quantitative methods that gather measurable data to achieve the objectives. The research conducted is to identify employability skills of engineering graduates in Malaysia, and observe the level of requirement for the skills. Questionnaire was chosen as a tool to gather the required data. The survey focuses on technical and soft (nontechnical) skills in an engineering discipline (Yuzainee et al., 2011). The responses were collected from 337 out of a random sample of 500 potential employers of engineering graduates around Kelang valley, Malaysia in September 2009 to January 2010. There were fifty attributes used to examine the required employability skills as valued by employers when hiring fresh engineering graduates. These fifty attributes had been grouped into ten key skills. The key skills are classified into five soft skills and five technical skills. The softskills are communication skills (EES1), teamwork (EES2), lifelong learning (EES3), professionalism (EES4), problem solving and decision-making skills (EES5). The five technical skills are competent in the application and practice (EES6), knowledge of science and engineering principles (EES7), knowledge of contemporary issues (EES8), engineering system approach (EES9) and competent in specific engineering discipline (EES10).

The questionnaire disseminated to high-rank officers in the companies in order to assure the accuracy of the results. They are from twelve types of industry's nature of business with six different levels of position in the organisation as presented in Table 1. The data were collected through face-to-face interviews, telephone interviews, email and snow-ball sampling. About 337 out of 500 engineering's employers responded and only $301(89.3 \%)$ are usable for analysis. The study employed statistical method to analyse profile of respondents and Multi-attribute value theory (MAVT) method to analyse the level of requirement for the skills. 
Table 1. Profile of respondents based on position in company and nature of business

\begin{tabular}{lcccccccc}
\hline Nature & Chairman & Chief Officer & Director & Manager & Senior Engineer & Others & Total & $\%$ \\
\hline N1 & 0 & 0 & 0 & 2 & 3 & 1 & 6 & 2.0 \\
N2 & 0 & 0 & 0 & 3 & 1 & 2 & 6 & 2.0 \\
N3 & 0 & 1 & 0 & 7 & 10 & 1 & 19 & 6.3 \\
N4 & 0 & 0 & 1 & 4 & 8 & 0 & 13 & 4.3 \\
N5 & 2 & 1 & 4 & 18 & 15 & 2 & 42 & 14.0 \\
N6 & 0 & 0 & 0 & 2 & 1 & 0 & 3 & 1.0 \\
N7 & 0 & 0 & 1 & 9 & 12 & 0 & 22 & 7.3 \\
N8 & 0 & 0 & 1 & 9 & 11 & 2 & 23 & 7.6 \\
N9 & 0 & 2 & 1 & 25 & 21 & 6 & 55 & 18.3 \\
N10 & 0 & 0 & 0 & 16 & 14 & 0 & 30 & 10.0 \\
N11 & 0 & 1 & 1 & 20 & 21 & 1 & 44 & 14.6 \\
N12 & 0 & 1 & 6 & 13 & 15 & 3 & 38 & 12.6 \\
Total & 2 & 6 & 15 & 128 & 132 & 18 & 301 & \\
$\%$ & 0.7 & 2.0 & 5.0 & 42.5 & 43.9 & 6.0 & & 100 \\
\hline N1- & 0 & 0.5 & & 13 & & 0 \\
\hline
\end{tabular}

N1-Healthcare and Social; N2-Leisure and Entertainment; N3-Education; N4-Commerce,Trade and Finance;

N5-Communications and IT; N6-Defence and Security; N7-Transport; N8-Agriculture and Food;

N9-Engineered Materials; N10-Energy and Natural Resources; N11-Built Environment; N12-Consulting.

The questionnaire requires respondents to assess quantitatively on the level of requirement on identified skills that should be owned by engineering graduates. Each skill rated by respondents using a five-point Likert scale representing different levels of requirement of skills. The responses "1" indicates "Extremely Not Required", "2" indicates "Not Required", "3" indicates "Slightly Required", "4" indicates "Required" and " 5 " indicates "Extremely Required". The weight, Normalised Skill Weight (NSW), index and level of requirement of skills were analyzed using the MAVT method adapted from Fishburn (1967) and Keeney \& Raiffa (1976). This paper is an extension of the study presented in EDUCON2011 (Yuzainee et al. 2011). The result shown in Table 2 has been presented in EDUCON2011. This paper presents and proposes a new mathematical formula to calculate score of the employability skills performed by engineering graduates in their job interview.

Table 2. Level of requirement of employability skills

\begin{tabular}{lllllc}
\hline Code & Skills and Criteria & Weight & NSW & Index & Level of requirement \\
\hline S1 & Communication skills & 0.1048 & 10.48 & 1.0000 & 1 \\
S2 & Teamwork & 0.1043 & 10.43 & 0.9961 & 2 \\
S3 & Lifelong Learning & 0.0988 & 9.88 & 0.9431 & 7 \\
S4 & Professionalism & 0.1013 & 10.13 & 0.9672 & 3 \\
S5 & Problem solving and decision making skills & 0.1012 & 10.12 & 0.9655 & 4 \\
S6 & Competency & 0.1011 & 10.11 & 0.9654 & 5 \\
S7 & Knowledge of science and engineering principles & 0.0997 & 9.97 & 0.9520 & 6 \\
S8 & Knowledge of contemporary issues & 0.0971 & 9.71 & 0.9273 & 8 \\
S9 & Engineering system approach & 0.0953 & 9.53 & 0.9097 & 10 \\
S10 & Competent in specific engineering discipline & 0.0964 & 9.64 & 0.9199 & 9 \\
& $\quad$ Total weight of S1 - S10 & 1.0000 & 100 & & \\
\hline Sour & Ylzain & & & \\
\end{tabular}

Source: Yuzainee (2011)

\section{Data Analysis and Computation of Results}

The NSW of ten employability skills (S1-S10) calculated using the weight of skills obtained from a report 
presented by Yuzainee et al. (2011). The $N S W$ determined by (1), adapted from Fishburn (1967) and Keeney \& Raiffa (1976). The employability score calculated using (2) by taking $N S W$ as a coefficient $\left(V_{n}\right)$ of each skill. The employability score is $V_{n}$ times the given score range 0 to 50 points divided by total score of each skill (50) obtained by applicant. Then the total score is a summation of employability score (3).

$$
N S W_{n}=\frac{X_{n}}{\sum_{n=1}^{i} X_{n}} \times 100
$$

where

$N S W$ - Normalised Skill Weight

$X_{n}$ - Weight of skill

$i$ - Number of skills $(i=5)$

$n-n^{\text {th }}$ term

$$
\text { Em ployability Score }(E S)=V_{n} * S_{n}
$$

and

$$
\text { Total Employability Score }=\sum_{n=1}^{i}\left(V_{n} * S_{n}\right)
$$

where

$V_{n}$ - Value of Normalised Skill Weight with

$S_{n}$ - Score of skill obtain by applicant $\left(M_{n}\right.$ /fullmark)

$i$ - Number of skills $(i=10)$

$n-n^{\text {th }}$ term

For this study, the calculation using (2) and (3) illustrated as following:

Total Employability Score

$=(10.48) \mathrm{S} 1+(10.43) \mathrm{S} 2+(9.88) \mathrm{S} 3+(10.13) \mathrm{S} 4+(10.12) \mathrm{S} 5+(10.11) \mathrm{S} 6+(9.97) \mathrm{S} 7+(9.71) \mathrm{S} 8+(9.53) \mathrm{S} 9$

\begin{tabular}{|c|c|c|c|c|c|c|c|c|c|c|}
\hline \multirow[t]{2}{*}{ Code } & \multirow[t]{2}{*}{ Skills and Criteria } & \multirow{2}{*}{$\begin{array}{l}\text { NSW } \\
\left(V_{n}\right)\end{array}$} & \multicolumn{2}{|c|}{ Full Mark } & \multicolumn{2}{|c|}{ Candidate 1} & \multicolumn{2}{|c|}{ Candidate 2} & \multicolumn{2}{|c|}{ Candidate 3} \\
\hline & & & $\mathrm{M}_{\mathrm{n}}$ & ES & $\mathrm{M}_{\mathrm{n}}$ & ES & $\mathrm{M}_{\mathrm{n}}$ & ES & $\mathrm{M}_{\mathrm{n}}$ & ES \\
\hline S1 & Communication skills & 10.48 & 50 & 10.48 & 30 & 6.29 & 25 & 5.24 & 45 & 9.43 \\
\hline S2 & Teamwork & 10.43 & 50 & 10.43 & 35 & 7.30 & 30 & 6.26 & 40 & 8.34 \\
\hline S3 & Lifelong Learning & 9.88 & 50 & 9.88 & 45 & 8.89 & 40 & 7.90 & 35 & 6.92 \\
\hline S4 & Professionalism & 10.13 & 50 & 10.13 & 40 & 8.10 & 40 & 8.10 & 30 & 6.08 \\
\hline S5 & Problem solving and decision making skills & 10.12 & 50 & 10.12 & 25 & 5.06 & 45 & 9.11 & 25 & 5.06 \\
\hline S6 & Competency & 10.11 & 50 & 10.11 & 25 & 5.06 & 40 & 8.09 & 30 & 6.07 \\
\hline S7 & Knowledge of science and engineering principles & 9.97 & 50 & 9.97 & 30 & 5.98 & 40 & 7.98 & 35 & 6.98 \\
\hline S8 & Knowledge of contemporary issues & 9.71 & 50 & 9.71 & 35 & 6.80 & 35 & 6.80 & 45 & 8.74 \\
\hline S9 & Engineering system approach & 9.53 & 50 & 9.53 & 40 & 7.62 & 30 & 5.72 & 40 & 7.62 \\
\hline \multirow[t]{5}{*}{$\mathrm{S} 10$} & Competent in specific engineering discipline & 9.64 & 50 & 9.64 & 45 & 8.68 & 25 & 4.82 & 25 & 4.82 \\
\hline & Total Point & & 500 & & 350 & & 350 & & 350 & \\
\hline & Total Employability Score & & & 100 & & 69.78 & & 70.01 & & 70.06 \\
\hline & Average & & & & 35 & & 35 & & 35 & \\
\hline & Percentage & & & & $70 \%$ & & $70 \%$ & & $70 \%$ & \\
\hline
\end{tabular}

+ (9.64) S10

Table 3. Example of score for three applicants

Table 3 shows an example of employability score obtained by three applicants using equation (2) comparing to 
score obtained by percentage and average.

\section{Discussion}

The evaluators of job interview judge the candidates according to the different levels of preference (1-50 points). According to Ryan and Hughes (1997) and agreed by Vick and Scott (1998) that the level of preference should be realistic and informative to make it competitive choices. In addition, the range of levels of preference should provide enough variation. The positive level of preference should be used because it does not seem reasonable for candidates with negative levels of preferences. Table 3 shows the example of employability score for ten employability skills obtained by three candidates. Total mark, percentage, and mean score are equal for these three candidates though they have different abilities. Equation (2), calculate employability score gives different value for these three candidates based on the coefficient $\left(V_{n}\right)$ of using NSW assigned to each skill. The coefficient shows that communication skills (10.48) are the skill with the strongest effect on the candidates, and it is considered for being the most influential and required skills for the candidates. Based on the coefficients of NSW, teamwork skills (10.43) ranked as second, and professionalism (10.13) as third required skills, while skill on having engineering system approach (9.53) are relative the least important for the candidate of the new engineer.

The example illustrated in Table 3 shows that Candidate 3 is the first choice followed by Candidate 2 as a second choice to succeed in a job interview. The employability score using average or percentage indicates the candidates obtained equal score. However, using Equation (1) and Equation (2), the Candidate 3 obtained better score compare to other two candidates. Candidate 3 shows better performance in communication skills and teamwork compared to the other two candidates. This gives him better opportunity to succeed in the interview. Though Candidate 1 shows slightly better performance in demonstrating the communication and teamwork skills compared with the performance of Candidate 2, but Candidate 1 performed the skills far lesser score than Candidate 2 in "problem-solving and decision making" and "competency". This make Candidate 2 is better than Candidate 1. The example demonstrates that the Equation (1) generates NSW which differentiate the candidates' skills according to the level of requirement of skills as perceived by the employers.

\section{Discussion}

Previous studies on soft skills, generic skills and employability skills, confirmed the significant of soft skills compared to technical skills (Zaharim et al. ,2009; Zaharim et al. ,2010; DEST, 2002; Yuzainee et al., 2010; DEST., 2006; Lee, 2003; MOHE, 2006). The equation (2) proposed in this study accommodates the needs of skills by having higher coefficient on soft skills compared to technical skills. The coefficients assigned for each skill, given by NSW (Equation 1), was based on the perception of employers regarding the level of requirement of the skills listed in MEES. The equation (2) and (3) is suitable to evaluate the performance of engineers as NSW (Equation (1)) obtained from employers' perspectives. Therefore, this study suggests an equation (2) and (3) to evaluate the new engineers in a job interview. Employers, who need to evaluate the quality of engineering graduates during interviews, might find this approach more effective in selecting new engineers.

\section{Acknowledgements}

This work supported by the Centre for Engineering Education Research, Faculty of Engineering and Built Environment, Universiti Kebangsaan Malaysia, Bangi, Selangor, Malaysia under the research grant PTS-2012-091. The authors also would like to thank Universiti Kebangsaan Malaysia for providing the research grant OUP-2012-126.

\section{References}

Ashton, D. N., \& Green, F. (1996). Education, training and the global economy. Cheltenham: Edward Elgar.

Borghans, L., Green, F., \& Mayhew, K. (2001). Skills measurement and economic analysis: An introduction. Oxford Economic Papers, 53(3), 375-384. http://dx.doi.org/10.1093/oep/53.3.375

DEST. (2002). Employability skills for Australian industry: literature review and framework development. Employability skills for the future. A report by the Australian Chamber of Commerce and Industry and the Business Council of Australia for the Department of Education, Science and Training, Canberra.

DEST. (2006). Employability skills from framework to practice, an introductory guide for trainers and assessors. A report by the Australian Chamber of Commerce and Industry and the Business Council of Australia for the Department of Education, Science and Training, Canberra.

Fishburn, P. C. (1967). Methods of estimating additive utilities. Management Science, 13(7). 
http://dx.doi.org/10.1287/mnsc.13.7.435

Hillage, J., \& Pollard, E. (1998). Employability: Developing a Framework for Policy Analysis. Research Report No. RR85, Department for Education and Employment (DfEE), London.

Kaufman, R., Thiagarajan, S., \& MacGillis, P. (1997). The Guidebook for Performance Improvement. San Francisco, California: Jossey-Bass/ Pfeiffer Publisher.

Keeney, R. L., \& Raiffa, H. (1976). Decisions with multiple objectives: Preferences and value tradeoffs. Wiley, New York.

Lee, F. T. (2003) Identifying essential learning skills in students' engineering education. Monash University Malaysia. Retrieved from http://surveys. canterbury.ac.nz/herdsa03/pdfsref/Y1111.pdf

MOHE. (2006). Ministry of Higher Education, Malaysia. The Future of Engineering Education in Malaysia. Department of Institutions of Higher Education Management, Ministry of Higher Education. ISBN 983-2982-1318.

Neely, A., Adams, C., \& Kennerly, M. (2002). The Performance Prism: The Scorecard for Measuring and Managing Business Success. London: Pearson Education Limited.

Robinson, J. P. (2000). What Are Employability Skills? Community Workforce Development Specialist, Alabama Cooperative Extension System, Volume 1, Issue 3.

Ryan, M., \& Hughes, J. (1997). Using conjoint analysis to assess women's preferences for miscarriage management. Health Economics, http://dx.doi.org/10.1002/(SICI)1099-1050(199705)6:3<261::AID-HEC262>3.0.CO;2-N

Silva, E. (2009). Measuring skills for 21st-century learning. Phi Delta Kappan, 90(9), 630-634.

Vick, S., \& Scott, A.(1998). Agency in health care. Examining patient's preferences for attributes of the doctor-patient relationship. Journal of Health Economics, 17, 587-605. http://dx.doi.org/10.1016/S0167-6296(97)00035-0

Yuzainee, M. Y., Omar, M. Z., \& Zaharim, A. (2011). Employability Skills for an Entry-Level Engineer as seen by Malaysian Employers. IEEE Global Engineering Education Conference. - Learning Environments and Ecosystems in Engineering Education, EDUCON2011. Princess Sumaya University for Technology. Amman, Jordan. http://dx.doi.org/10.1109/EDUCON.2011.5773117

Zaharim, A., Md Yusoff, Y., Omar, M. Z., Mohamed, A., Muhamad, N., \& Mustapha, R. (2009). Engineering Employability Skills Required By Employers In Asia. 6th WSEAS International Conference on ENGINEERING EDUCATION (EE '09), Rodos, Greece, pp195 - 201.

Zaharim, A., Omar, M. Z., Yuzainee, M. Y., Muhamad N., Mohamed, A., \& Mustapha, R. (2010). Practical Framework of Employability Skills for Engineering Graduate in Malaysia. IEEE Engineering Education $\begin{array}{lllll}\text { Conference } & \text { (EDUCON } 2010) . & \text { Madrid/Spain14-16 }\end{array}$ http://dx.doi.org/10.1109/EDUCON.2010.5492478 